\title{
KONSEP TRI UGERING NGAURIP MANGKUNEGARA IV SEBAGAI MOTIVASI \\ PENGEMBANGAN KEWIRAUSAHAAN: PERSPEKTIF PENDIDIKAN ISLAM
}

Susiyanto

\begin{abstract}
Tri Ugering Ngaurip is a teaching developed by K.G.P.A.A. Mangkunegara IV, the king of the Kraton Mangkunegaran - Surakarta, in his work called Serat Wedhatama which contains three handles of life that must be owned by Javanese society. With these three concepts, the community will have a motivating guide in developing skills and achieving life direction based on Islamic perspectives that tend to be tassawuf.

Tri ugering Ngaurip concept is interesting to be discussed because it reveals financial independence, guarding honor, and trying to gain intelligence. These three things are stated to be the handle of Javanese people's life which includes arta (wealth or economy), wirya (glory), and winasis (intelligence). In the realm of education development, it should be directed towards achieving these three categories. This concept is actually a description of the Javanese philosophical expression of "work" by choosing the term "pangupa soul pangupa" (looking for food for the soul).

Wirya means honor, nobility, and dignity possessed by someone in his community. This concept also includes moral and ethics that must be possessed by someone in the process of social interaction. Arta or economy plays a role in people's lives. While Winasis is directed at the conception of multidimensional intelligence, namely emotional, intellectual, and spiritual.

The achievement of tri ugering ngaurip is a motivation that underlies Javanese society to cultivate a livelihood, including the world of entrepreneurship. Practicing tri ugering ngaurip in life is actually the practice of trying to carry out religious obligations to earn a living. Therefore, the implementation of Islamic education should be insighted tri ugering urip, both as a motivation in developing entrepreneurship and in a more practical realm. This is actually an obligation that has been included from the beginning to Muslims.
\end{abstract}

Keyword(s): serat wulang, arta, wirya, winasis 


\begin{abstract}
ABSTRAK
Tri Ugering Ngaurip adalah ajaran yang dikembangkan oleh K.G.P.A.A. Mangkunegara IV, raja Kraton Mangkunegaran - Surakarta, dalam karyanya yang bernama Serat Wedhatama yang berisi tiga pegangan hidup yang harus dimiliki oleh masyarakat Jawa. Dengan ketiga konsep tersebut maka masyarakat akan memiliki suatu panduan yang memotivasi dalam pengembangan kemampuan dan pencapaian arah hidup berdasarkan cara pandang Islam yang cenderung bercorak tassawuf.

Konsep tri ugering ngaurip ini menarik untuk dibahas sebab mengungkapkan tentang kemandirian finansial, penjagaan kehormatan, dan upaya memperoleh kecerdasan. Ketiga hal ini tertuang menjadi pegangan hidup masyarakat Jawa yang mencakup arta (kekayaan atau ekonomi), wirya (kemuliaan), dan winasis (kecerdasan). Dalam ranah pengembangan pendidikan mestinya diarahkan untuk mencapai ketiga kategori tersebut. Konsep ini sejatinya merupakan penjabaran dari ungkapan filosofis Jawa tentang "bekerja" dengan memilih term "nggolek pangupa jiwa" (mencari santapan bagi jiwa).

Wirya bermakna kehormatan, keluhuran, dan martabat yang dimiliki oleh seseorang dalam masyarakatnya. Konsep wirya ini juga mencakup moral dan etika yang harus dimiliki oleh seseorang dalam proses interaksi sosialnya. Arta atau ekonomi memegang peranan dalam kehidupan masyarakat. Sedangkan Winasis diarahkan pada konsepsi kecerdasan multidimensional yaitu emotional, intelektual, dan spiritual.

Pencapaian terhadap tri ugering ngaurip merupakan motivasi yang melandasi masyarakat Jawa untuk menggeluti suatu mata pencarian, termasuk di dalamnya dunia kewirausahaan. Mempraktikkan tri ugering ngaurip dalam kehidupan, sejatinya merupakan praktik dari upaya menjalankan kewajiban agama untuk memperoleh nafkah. Oleh karena itu penyelenggaraan pendidikan Islam mestinya berwawasan tri ugering ngurip, baik sebagai motivasi dalam menumbuh kembangkan kewirausahaan maupun dalam ranah yang lebih praksis. Hal ini sejatinya merupakan kewajiban yang sejak awal telah include kepada umat Islam.
\end{abstract}

Keywords: serat wulang, arta, wirya, winasis 


\section{A. PENDAhuluan}

Masyarakat Nusantara di masa lalu mestinya memiliki etos kewirausahaan yang tinggi. Motifnya bukan sekedar "make money" sebagaimana motivasi kewirausahaan Barat yang mengesankan pragmatism. Pandangan masyarakat Indonesia tentang "bekerja" dan "pekerjaan" lebih mendalam dari sekedar tuntutan untuk memenuhi kebutuhan duniawi. Jadi, bukan sekedar terjebak dalam pragmatisme semata, namun masyarakat Nusantara memiliki pemikiran yang lebih mendalam dan filosofis.

Kebudayaan masyarakat muslim Jawa di masa lalu sebagai bagian dari khazanah Nusantara telah membuktikan hal tersebut. Contoh yang dapat dikemukakan di sini diantaranya adalah kisah tentang Nyi Ageng Pinatih dan anak angkatnya, Jaka Samudra (Raden Paku), yang diketahui sebagai pengusaha yang melakukan perniagaan antar pulau di Nusantara. (Sunyoto, 2016).

Tentu tidak dapat dinafikan pula bahwa salah satu teori tentang penyebaran Islam di seantero Indonesia, diantaranya mula-mula diawali oleh kegiatan dakwah yang dilakukan oleh para pedagang dari berbagai wilayah negara Islam. (Yunus, 2008). Persentuhan antara para saudagar muslimdengan penduduk setempat, bukan hanya menyatukan mereka di bawah paying satu agama, namun juga dalam penumbuhan kekuatan ekonomi baru yang pada giliran selanjutnya merambah ranah politik dengan berdirinya kerajaan-kerajaan Islam di
Nusantara. (Tjandrasasmita, 2009). Spirit semacam ini tentu perlu dikembangkan oleh para penyelenggara pendidikan Islam sebagai motivasi untuk membawa umat kepada kebangkitan ekonomi melalui dunia kewirausahaan.

Kisah Jaka Samudra di atas memperlihatkan bahwa upaya mencari nafkah melalui perdagangan antar pulau yang dilakukan oleh dua orang penguasaha Jawa di masa lalu bukan sekedar berujung pada pencarian kehidupan profan. Sambil berniaga ia juga meningkatkan kapasitas keilmuannya dengan berguru kepada ulama-ulama yang berasal Jawa maupun tanah seberang. (Abdullah, 2015). Pada akhirnya ia menjadi salah satu propagandis Islam paling berpengaruh di Jawa dan dikenal sebagai salah satu anggota Wali Sanga yang bernama Sunan Giri. Demikianlah tipologi wirausahawan Jawa pada masa itu.

Mereka adalah saudagar muslim Jawa yang melakukan perniagaan hingga ke luar Jawa. Semangat berwirausaha ini juga dibarengi dengan tradisi menuntut ilmu dan penyempurnaan spiritualisme. Tema-tema semacam ini nampaknya perlu diangkat untuk memperlihatkan bahwa masa lalu bangsa Indonesia dapat berfungsi sebagai inspirasi, termasuk dalam dunia kewirausahaan.

Hal yang cukup menarik untuk dikupas di sini adalah pandangan masyarakat Jawa terhadap pekerjaan atau profesi. Istilah yang sering digunakan untuk memperbincangkan 
tentang "bekerja biasanya menggunakan term "golek panguripan". Ungkapan ini bermakna bahwa bekerja sejatinya merupakan upaya untuk "mencari kehidupan". Dalam ungkapan ini sejatinya mengadung pengertian yang lebih mendalam bahwa berkeja bukan sekedar untuk mempertahankan kehidupan di dunia, namun masyarakat Jawa secara umum memiliki pandangan yang mencakup kehidupan spiritual.

Hal tersebut diungkapkan dalam penggunaan istilah "bekerja" selanjutnya, yaitu penggunaan kata "golek pangupa jiwa". Kata golek sendiri bermakna mencari, sedangkan pangupa berasal dari kata dasar upa yang artinya "butiran nasi dari beras". Menariknya kata "upa" ini dikombinasikan dengan kata jiwa, sehingga secara leksikal ungkapan golek pangupa jiwa membentuk makna "mencari butiran nasi untuk jiwa" atau dalam Bahasa yang lebih lugas memberi pengertian "mencari makanan untuk jiwa".

Penggunaan kata "golek pangupa jiwa" semacam ini tentu memiliki nilai filosofis yang tinggi. Lebih bermakna dari sekedar "membuat uang" yang berasal dari penerjemahan kata "make money" yang bersumber dari pandangan dan latar belakang masyarakat Barat. Dalam pandangan masyarakat Jawa, uang yang diperoleh dari sebuah usaha bukan sekedar alat tukar untuk memindahkan nilai dan manfaat suatu barang atau jasa dari satu pihak kepada pihak lain. Pandangan Jawa tentang konsep rizki menunjukkan bahwa kedalaman dimensi spiritual dalam bekerja turut memberi motivasi.
Uang bukan hanya berdimensi material semata, namun juga masuk dalam wilayah spiritual.

Ungkapan "golek pangupa jiwa" di atas sejatinya merupakan upaya yang berasal dari alam sadar untuk menanamkan spirit penting ke dalam alam bawah sadar agar nilai-nilai spiritualitas dihayati dan internalisasidalam seluruh aspek kehidupan. Spirit semacam ini tentu akan menyediakan lebih banyak hal-hal menarik jika dikaji secara mendalam. Kajian semacam ini juga akan menjadi salah satu cara yang dapat digunakan untuk pewarisan nilainilai dan spirit positif dari masa lalu agar tetap hidup dan mengalir dalam urat nadi anak bangsa.

Berdasarkan pemahaman di atas, maka penulis akan berupaya untuk mengeksplorasi pandangan Jawa tentang konsep bekerja atau menguasahakan mata pencarian, termasuk di dalamnya adalah dunia kewira usahaan. Tulisan ini akan lebih dikonsentrasikan untuk membahas motivasi kewirausahaan yang berasal dari warisan tradisi lokal Jawa. Harapannya, generasi hari ini dan dunia keilmuan dapat memahami bahwa sejarah kebudayaan bangsa Indonesia telah mewariskan nilai-nilai kearifan yang berharga untuk dieksplorasi.

Konsep tri ugering ngaurip sebagai bagian dari isi naskah Serat Wedhatama, sebuah karya didaktik tentang etika dan moralitas Jawa yang ditulis oleh K.G.P.A.A. Mangkunegara IV, menarik untuk didalami 
guna membahas tentang motivasi kewirausahaan tersebut.

Berbicara tentang motivasi maka tentu umat Islam akan menghubungkannya dengan niat. Mengaca pada hadits "innama a'malu biniyyat" (Sesungguhnya segala sesuatu perbuatan tergantung pada niat), maka motivasi yang dimiliki oleh pribadi muslim tentunya tidak boleh sembarangan. Motivasi tersebut harus bersumber pada pandangan hidup (worldview) yang Islami dengan mengedepankan niat yang positif.

Tulisan ini akan berupaya untuk mengupas tentang Konsep Tri Ugering Ngaurip Mangkunegara IV sebagai Motivasi Pengembangan Kewirausahaan dalam Perspektif Pendidikan Islam. Harapannya, kosep tersebut akan dapat dikembangkan dalam mendukung dunia kewirausahaan terutama dalam aspek motivasi. Tujuan yang tidak kurang penting dari itu adalah mengangkat kearifan lokal milik bangsa agar lebih dikenali dan dihargai sebagai bagian dari khazanah kebudayaan Indonesia. Pada saat yang sama juga menunjukkan peran Islam dalam memberikan spirit dan substansi positif terhadap aspek-aspek kebudayaan tersebut.

\section{B. SERAT WEDHATAMA}

Serat Wedhatama adalah karya Kanjeng Gusti Pangeran Adipati Arya (K.G.P.A.A.) Mangkunegara IV. Selanjutnya disebut Mangkunegara IV. Naskah yang ditulis oleh raja atau adipati Mangkunegaran, Surakarta ini merupakan sebuah teks sastra yang mengandung pengajaran moralitas dan etika. Naskah ini ditulis dengan menekankan nafas Islam yang cukup kental di dalamnya, terutama dalam dimensi tasawwuf.

Bukan hanya sebagai seorang raja yang memerintah Kadipaten Mangkunegaran, Surakarta, yang memerintah antara 25 Maret 1853 hingga 2 September 1881, Mangkunegara IV juga dikenal sebagai seorang Pujangga yang menghasilkan lebih dari 30 karya. (Santosa, 2011). Ini merupakan pencapaian yang sangat luar biasa, mengingat kesibukan yang dimilikinya sebagai seorang penguasa politik dan sekaligus militer.

Ia hidup pada masa dimana sastra Jawa telah memasuki era baru yang disebut sebagai “jaman kebangkitan” dunia kapujanggan. Masa ini ditandai dengan hidupnya banyak pujangga baik di lingkungan Kraton maupun di luar. (Sukri, 2004). Raden Ngabehi Ranggawarsita adalah salah satu pujangga besar Jawa yang hidup sejaman dengannya dan bahkan ikut terlibat mengedit karya-karya milik raja, termasuk Mangkunegara IV.

Serat Wedhatama merupakan salah satu karya penting yang dihasilkan oleh Kanjeng Gusti Pangeran Arya Adipati Mangkunegara IV, raja dari sebuah kadipaten otonom yang berada di bawah kekuasaan Kraton Kasunanan Surakarta. Naskah ini termasuk teks penting dan terkenal dalam pengajaran didaktik etika dan moralitas di lingkungan kebudayaan Jawa. Termasuk dalam kategori serat wulang artinya 
ditulis sebagai karya yang berisi pengajaran tentang nilai-nilai moral dan etika.

Secara sederhana dapat dikatakan bahwa naskah ini merupakan buku ajar yang berbentuk sastra namun berisi nilai-nilai luhur. Melalui naskah ini, sang raja Mangkunegaran tersebut nampaknya hendak menularkan spirit keislaman dan sekaligus kejawaan kepada kawula alit (rakyat kecil) yang berada di bawah tanggung jawabnya. Dalam suasana feudal masa itu, dimana media informasi belum banyak dimiliki, karya sastra merupakan sebuah sarana yang efektif bagi penyebaran informasi yang berisi nasehat, kebijakan, atau pengajaran dari pihak kerajaan kepada rakyatnya.

Diantara isinya, berkaitan dengan kemandirian ekonomi yang harus dimiliki oleh umat manusia. Mangkunegara IV menekankan bahwa kekuatan finansial menjadi faktor penting keberlangsungan hidup manusia. Pengaruhnya meliputi eksistensi manusia dimana ia akan dihormati dan dihargai diantaranya melalui kemandirian. Untuk itu maka menurut Mangkunegara IV, manusia harus bekerja untuk menghidupi dirinya agar terselenggara kehidupan yang sejahtera lahir dan batin. Ajaran inilah yang kemudian dituangkan dalam bentuk motivasi melalui konsep tri ugering ngaurip.

\section{TRI UGERING NGAURIP SEBAGAI MOTIVASI KEWIRAUSAHAAN}

Konsep tri ugering ngaurip sendiri secara kamus dapat diartikan sebagai "tiga hal yang menjadi patokan atau pedoman kehidupan". Konsep penting yang digagas oleh Mangkunegara IV ini terdapat dalam Serat Wedhatama pupuh II tembang Sinom pada (bait) 15 sebagai berikut:

\section{"Bonggan kang tan mrelokena, mungguh ugering ngaurip; \\ uripe lan tri prakara: \\ wirya, arta, tri winasis; \\ Kalamun kongsi sepi; \\ saka wilangan tetelu; \\ telas tilasing janma; \\ aji godhong jati aking;}

temah papa papariman ngulandara".

[Kesalahannya sendiri bagi yang tidak melaksanakan berkaitan dengan pokok mata pencarian hidup yang berjumlah tiga perkara yaitu wirya, arta, dan yang ketiga winasis. Jika ketiganya tidak dimiliki maka habislah harga diri manusia, masih lebih berharga daun jati yang kering, akhirnya menderita dan menggelandang]. 
Dalam masyarakat Jawa, nampaknya ketiga motivasi diatas menentukan strata seseorang dalam masyarakat. Posisi tersebut biasanya menentukan pula peran dan pengaruh yang bersangkutan dalam lingkungan sosialnya. Maka tidak mengherankan hal-hal semacam itu lantas menjadi motivasi bagi individu dalam masyarakat untuk mengejarnya.

Adapun penjelasan konsep-konsep yang termuat dalam tri ugering ngaurip adalah sebagai berikut:

\section{WIRYA}

Kata "wirya" artinya kêndêl (berani), kuwasa (berkuasa); mulya (mulia), dan luhur. (Poerwadarminta, 1943). C.F. Winter memaknai kata ini dengan arti luhur, mukti, wiyar, sadaya, sae, kaluhuran, kamulyan, kamuktèn, kasaktèn, kaprawiran, dan prajurit. (Winter, 1928). R. Soedjonoredjo memaknai kata wirya dengan "derajat" atau "pangkat" yang memungkinkan dapat digunakan untuk mendapatkan gaji. (Soedjonoredjo, 1937).

Dalam permasalahan wirya (kehormatan) ini seringkali dibicarakan tentang konsep jeneng lan jenang. Jeneng secara literal bermakna "nama". Istilah ini biasanya digunakan untuk menjelaskan tentang bagaimana nama seseorang akan dikenali atau dalam Bahasa yang lebih sederhana berkaitan dengan bagaimana upaya seseorang untuk mengharumkan namanya agar dikenal oleh masyarakat.
Sementara jenang sebenarnya mengacu pada nama sejenis makanan yang ada di Jawa. Penggunaan kata ini biasanya dihubungkan dengan keuntungan-keuntungan yang diperoleh seseorang apabila namanya telah dikenal atau diakui oleh masyarakat di sekelilingnya. Oleh karena itu ungkapan ngutamakake ngupaya jeneng, mangko jenange bakal melu (utamakan mencari nama maka jenang akan ikut) bermakna bahwa seseorang harus mengupayakan agar dirinya mendapat pengakuan. Apabila nama baik telah diperoleh maka kenikmatan hidup lainnya dengan sendirinya akan mengikuti.

\section{ARTA}

Sementara kata arta menunjuk pada uang, harta, atau kekayaan. Arti ini sejalan dengan pemaknaan yang diberikan oleh Soedjonoredjo. Ia bahkan menambahkan bahwa arta ini bisa dimaknai sebagai pawitan (modal, capital) untuk melakukan praktik kewirausahaan dalam berbagai bidang seperti perdagangan, pertanian, pertukangan, dan lain sebagainya. (Soedjonoredjo, 1937). Dengan demikian makna arta di sini juga mengandung pengertian terhadap sejumlah harta yang berdasarkan manfaatnya dapat difungsikan sebagai instrumen investasi.

Anjuran untuk memperoleh penghasilan dengan berwirausaha ini juga pernah diungkapkan oleh Pakubuwana IX, raja Kasunanan Surakarta, yang hidup hamper sejaman dengan MAngkunegara IV. Kepada 
kaum lelaki, ia berpesan untuk giat mencari nafkah bagi keluarganya. Nasehat sang raja ini merupakan salah satu upaya untuk mengikuti sunah Nabi Muhammad. (Mangunlesana, ed., 1975). Hal itu dapat ditemukan dalam karya Pakubuwana IX, Serat Kidung Sesingir, dalam pupuh VI tembang Pocung bait 16 dan 17 sebagai berikut:

"Lamun sira aneng wisma duh wong bagus, nyambiya pakaryan, nira kang maedahi, dimen jenak atinira aneng wisma.

Anenandur ingkang ana asilipun, tabik Rasulullah, wohing glalakirna dadi, kang minangka napkahing garwa lan putra”.

[Jika engkau berada di rumah wahai lelaki tampan, lakukanlah pekerjaanmu yang bermanfaat, agar hatimu betah berada di rumah.

Tanamlah sesuatu yang menghasilkan, mengikuti ajaran Rasulullah, buah dari tanaman dipekarangan akan bisa digunakan sebagai nafkah untuk istri dan anak.]

Bekerja adalah sebuah kewajiban bagi seorang laki-laki karena ia memiliki tanggung jawab untuk menafkahi keluarganya. Dalam konsep Islam, Allah menjanjikan rizki bagi mereka yang mengambilnya dengan melakukan sebuah pekerjaan. (QS. Al-Mulk : 15). Selain itu banyak terdapat anjuran dari Rasulullah SAW agar kaum laki-laki bekerja. Misalnya hal ini disampaikan Rasulullah saw sebagai berikut: “... Jika ada seeorang keluar dari rumahnya untuk bekerja guna membiaya anaknya yang masih kecil, maka ia telah berusaha Fisabilillah. Jikalau ia bekerja untuk dirirnya sendiri agar tidak sampai memintaminta pada orang lain, itupun Fisabilillah. Tetapi apabila ia bekerja untuk pamer atau untuk bermegah-megahan, maka itulah Fisabili Syaithan atau karena mengikutu jalan Syaithan." (HR. Thabrani)

Bekerja untuk memenuhi konsep arta (finansial), sejatinya juga merupakan bagian dari upaya untuk menjaga konsep winasis (kehormatan). Sebab orang yang tidak bekerja dan menjadi pengangguran biasanya akan distigma secara negatif oleh masyarakat. Demikian juga para pemilik lapangan pekerjaan, yang secara umum terdiri dari kalangan usahawan, biasanya mendapatkan posisi lebih utama dalam strata dan peran sosial.

\section{WINASIS}

Kata winasis berasal dari kata dasar wasis yang bermakna pandai, pintar, atau cerdas. Jadi, winasis menunjukkan kecerdasan atau kepintaran. Sementara arta dimaknai sebagai uang atau kekayaan. Sedangkan winasis artinya "kepintaran" yang fungsinya akan mengarahkan manusia untuk mendapatkan kehidupan yang lebih baik. Jika 
salah satu dari ketiga hal tersebut tidak dimiliki manusia maka kehidupannya nyaris tidak berharga. Ia akan menderita dan bahkan menggelandang ke sana kemari.

Winasis berhubungan langsung dengan kecerdasan, kepintaran, keahlian, atau kemampuan seseorang. Konsep winasis ini secara umum diarahkan untuk mendukung profesionalisme. Membicarakan hal ini tentu kosepnya harus dibawa kepada orang-orang yang memiliki profesi. Seseorang dikatakan memiliki profesi apabila (1) pekerjaan yang dilakukan membutuhkan suatu kemampuan tertentu (keahlian) (2) Profesi ini dipilih sebagai panggilan hidup (3) Profesi biasanya dlengkapi dengan kemampuan diagnostik dan kompetensi aplikatif (4) Profesi biasanya memiliki orang-orang yang membutuhkan pelayanan (client). (Tafsir, 2012a).

Konsep kecerdasan yang dimiliki masyarakat Jawa bukan sekedar mewakili kecerdasan dalam ranah intelektual (Intelectual Qoutient). Menurut Ahmad Tafsir, IQ merupakan kecerdasan bawaan (sejak lahir) manusia. IQ tidak dapat ditingkatkan, namun bisa dilatih agar aktual efektif. Dengan demikian menjadi tugas pendidikan untuk melatihnya. (Tafsir, 2012b). IQ yang terlatih akan mendukung kemampuan seseorang dalam berwirasuaha terutama dari sisi perencanaan dan mengupayakan strategi-strategi terbaik untuk mencapai produktivitas.

Lebih dari itu sejak awal, masyarakat Jawa telah mengenal penggunaan ungkapan kecerdasan yang dilekatkan pada spiritualitas. Istilah "wong pinter" (orang pintar), biasanya digunakan untuk memanggil orang-orang yang dianggap memiliki maqam spiritualitas cukup tinggi. Meskipun akhir-akhir ini istilah ini sering digunakan sebagai penyebutan untuk para dukun atau paranormal, namun pada masa lalu juga digunakan untuk menyebut seorang guru atau ulama.

Dengan demikian dalam pemahaman masyarakat Jawa, konsep Spiritual Qoutient (SQ) atau kecerdasan spiritual, bukan merupakan gagasan yang baru. SQ sendiri sejatinya, menurut Ari Ginanjar, adalah memberi makna ibadah terhadap semua tindakan yang dilakukan. Dengan demikian semua perbuatan manusia akan memiliki dimensi ibadah dan selanjutnya merupakan bagian dari sikap keberserahan kepada Allah SWT. (Agustian, 2004)

Konsep tri ugering ngaurip di atas sejatinya membuka gagasan filosofis dari ungkapan "golek pangupa jiwa" yang telah dibicarakan di atas. Istilah yang terakhir ini mewakili kedalaman rasa yang dihayati oleh masyarakat sebagai bagian dari cita-cita spiritualitas yang muncul dalam alam bawah sadar kebudayaan Jawa. Dalam bagian lain Serat Wedhatama bahkan sembah rasa yang bermakna ibadah dengan penghayatan terhadap rasa tertinggi dianggap sebagai tahapan spiritualitas puncak yang berada di atas sembah raga, sembah cipta, dan sembah jiwa. 
Sembah raga dalam Serat Wedhatama digambarkan dalam pupuh IV tembang Gambuh pada (bait) 2 sebagai berikut:

"Sembah raga puniku; pakartining wong amagang laku; sesucine asarana saking warih; kang wus lumrah limang wektu; wantu wataking wawaton".

(Sembah raga itu merupakan pekerjaan dari orang yang menjalankan laku. Cara bersucinya dilakukan dengan menggunakan air. Hal ini sudah wajar dilakukan sebanyak lima waktu sebagai tahapan mendasar yang harus dijalani).

Bedasarkan bait tembang di atas sembah raga menunjukkan peribadatan yang dijalankan oleh raga. Mangkunegara mencontohkan bahwa wujud sembah raga ini berupa shalat yang dilakukan lima waktu. Bersucinya dilakukan dengan menggunakan air yang menunjukkan aplikasi wudlu. Dalam pandangan Mangkunegara IV, sembah raga sejatinya merupakan penggambaran dari tingkatan spiritualitas dalam tataran syari'ah. Dalam bagian ini manusia masih berkutat dengan perilaku-perilaku fisikal dan terikat oleh bentuk (form). Meskipun demikian, syariah merupakan hal yang sangat mendasar dan menjadi pondasi dari sebuah bangunan spiritualitas. Dengan demikian keberadaannya tidak boleh diabaikan, apalagi ditinggalkan.
Sembah raga sendiri sering dikatakan sebagai representasi perjalanan dalam menempuh tataran syari'ah.

Sembah kalbu atau juga sering disebut sebagai sembah cipta dapat ditemukan dalam Serat Wedhatama pupuh IV tembang Gambuh bait 11 dan 12 sebagai berikut:

Samengko sembah kalbu; yen lumintu uga dadi laku;

laku agung kang kagungan narapati; patitis teteking kawruh; meruhi marang kang momong.

Sucine tanpa banyu; amung nyênyuda ardaning kalbu; pambukane tata titi ngati-ati;

atêtêp talatèn atul;

tuladan marang waspaos.

(Adapun sekarang sembah kalbu jika dilaksanakan juga bisa menjadi laku. Hal ini merupakan tindakan besar yang dilakukan oleh raja. Menjadi waspada dalam mendapatkan pengetahuan. Mengetahui terhadap yang mengasuh

Bersucinya tanpa air namun hanya dilakukan dengan mengurangi nafsu dalam hati. Diawali dengan ketelitian, kehati-hatian, istiqomah, dan ketelatenan. Menjadi contoh dalam kewaspadaan). 
Sembah kalbu merupakan tingkat lebih lanjut dari sembah raga. Jika sembah raga menekankan usaha pensucian diri yang bersifat fisikal, maka sembah kalbu menekankan pada pengekangan terhadap hawa nafsu. Dalam tahapan ini seorang pelaku sembah hendaknya memulai dengan pembersihan diri dari perbuatan-perbuatan tercela yang merusak kesucian hati. Dengan demikian tahapan kedua ini sejatinya adalah pembersihan hati (tazkiyah an-nafs).

Adapun sembah jiwa dapat ditemukan dalam Serat Wedhatama pupuh IV tembang Gambuh bait 16 sebagai berikut:

Samengko kang tinutur;

Sembah katri kang sayekti katur;

Mring Hyang Sukma suksmanen saari-ari;

Arahen dipun kecakup;

Sembahing jiwa sutengong.

(Sekarang yang diceritakan sembah yang ketiga yaitu peribadatan kepada Tuhan yang menguasai sukma, jadikan sukmamu bersama Dia dalam kehidupan sehari-hari. Usahakan agar hal itu bisa dilaksanakan sehingga mewujud dalam sembah jiwa)

Dengan demikian sembah jiwa sejatinya adalah tunduknya jiwa agar senantiasa berada dalam aturan Allah. (Soedjonoredjo, 1937). Seolah-olah sukma kita dalam frekuensi yang sama dengan kehendak
Allah, sehingga apa pun aturan-Nya maka harus menjadi bagian dari sikap dan tindakan manusia

Terakhir, sembah rasa dapat ditemukan dalam Serat Wedhatama pupuh IV tembang Gambuh bait 23 sebagai berikut:

Samengko ingsun tutur;

gantya sembah ingkang kaping catur;

sembah rasa karasa wosing dumadi;

dadi wus tanpa tuduh;

mung kalawan kasing batos.

(Sekarang aku memberikan nasehat agar mengganti kepada sembah yang keempat. Sembah rasa yaitu merasakan semua intisari kejadian. Dengan demikian tidak membutuhkan rukun dan syarat sebab hanya mengandalkan kekhususan yang berasal dari batin).

Inti dari sembah rasa ini menjelaskan bahwa irama rasa yang dimiliki oleh manusia hendaknya beresonansi dalam rasa yang dimiliki Allah. Sembah rasa ini merupakan manifestasi dari tingkatan makrifatullah dalam dunia tassawuf. Dimana perubahan gerak, rasa, dan pemikiran selalu diusahakan untuk menyadari kehadiran dan kehendak Allah, Rabb semesta alam. Dengan demikian konsep winasis sendiri sejatinya telah mengakui keberadaan konsep kecerdasan spiritual (SQ) sejak awal, sebagaimana termaktub dalam bangunan pemikiran Serat Wedhatama. 


\section{PERSPEKTIF PENDIDIKAN ISLAM}

Pendidikan Islam hendaknya mengarahkan peserta didik agar mampu mengembangkan fithrah sesuai dengan konsep Islam. Pengembangan fithrah ini akan bermuara pada kesejahteraan secara lahir maupun batin dan pada giliran selanjutnya mengutamakan kehidupan berdimensi akhirat. (Dakir dan Sardimi, 2011). Dengan demikian maka pendidikan Islam hendaknya diarahkan agar mampu mengembangkan seluruh potensi yang dimiliki oleh anak didik, termasuk diantaranya pengembangan potensi kreatif.

Kewirausahaan sejatinya merupakan bagian dari proses kreatif ini. Selama perjalanan kehidupannya manusia, bukan hanya harus mengutamakan kehidupan rohani, namun juga dituntut untuk memenuhi hajathajat jasmaninya. Termasuk di dalamnya adalah memakmurkan bumi, sebuah konsekuensi logis menjalankan fungsi sebagai khalifah fil ardhi. Kesadaran terhadap tugas eksistensial ini merupakan bagian dari upaya pembentukan konsep manusia yang seutuhnya menurut worldview Islam, yang biasanya dikenal sebagai insan kamil.

Tugas dan tanggung jawab untuk memakmurkan bumi dan menjaga keberlangsungannya merupakan sebuah amanah besar yang menjadi embanan bani Adam. Keberlangsungan ekonomi menjadi salah satu faktor penentu yang penting dalam cakupan isu ini. Bagaimana pun pendidikan Islam harus menempuh jalan dimana kemandirian secara finansial dari umat menjadi perhatian serius yang harus ditekuni. Di sinilah para penyelenggara dan stake holder pendidikan berbasis nilai keagamaan memiliki kepentingan strategis untuk menopang lahirnya wirausahawan-wirausahawan muslim.

Motivasi merupakan salah satu faktor pendorong kewirausahaan yang cukup penting. Motivasi itu sendiri dimaknai sebagai sebuah kondisi yang menyebabkan atau menimbulkan perilaku tertentu dan mampu memberikan arah serta ketahanan untuk tetap menjalankan tindakan tersebut. (Sugihartono, et all, 2007). Dalam pengertian ini terlihat bahwa motivasi bisa berperan sebagai pendorong dan pemelihara sebuah spirit.

Untuk menciptakan suatu perubahan yang mendasar setidaknya harus dibangun sebuah motivasi yang kuat, mindset yang tepat, dan make it (lakukan saja). (Kasali, 2012). Konsep tri ugering ngaurip sendiri akan mendorong hasrat untuk maju, memiliki langkah yang terarah, dan bisa berbuat lebih banyak.

Konsep tri ugering ngaurip, yang membicarakan tentang kehormatan, harta, dan kecerdasan, pada dasarnya merupakan sebuah motivasi yang sangat dekat berhubungan dengan eksistensi manusia. Motivasi ini secara langsung dapat dikaitkan dengan persoalan jati diri, kedudukan, dan peran manusia serta keberadaannya sebagai individu dalam suatu masyarakat. Problem eksistensial ini sejatinya merupakan masalah asasi (ultimate problems) 
sebab manusia secara serius selalu terkondisikan untuk mempertanyakan tentang dirinya seiring dengan perkembangan kemampuan dalam mencermati kehidupan dan proses kematangan pemikiran. (Supadie, et all, 2015a).

Di sini upaya menjaga wirya (kehormatan), arta (harta), dan winasis (kecerdasan) sejatinya merupakan bagian dari upaya pemeliharaan maqashid syari'ah (maksud-maksud atau tujuan-tujuan yang terkandung dalam syari'at). Dimana dalam konsep ad-dharuriyah al-khamsyah terdapat pengakuan untuk pemeliharaan terhadap akal (hifdz al-aql) yang sejalan dengan terminologi winasis. Juga pemeilharaan terhadap keturunan (hifdz an-nasl) yang sejatinya bertujuan pula untuk menjaga kehormatan sehingga meski tidak persis sama namun sejalan dengan konsep wirya. Demikian juga konsep arta (harta, finansial) pada dasarnya sejalan dengan pemeliharaan terhadap harta (hifdz al-mal). Terwujudnya pemeliharaan terhadap kemaslahatan individu dan sosial akan menjamin terpeliharanya tuntutan syari'ah untuk mengarahkan manusia menuju kehidupan yang mulia. (Supadie, et all, 2015b)

Mengangkat konsep tri ugering ngaurip dalam ranah pendidikan Islam artinya mengangkat kembali nilai-nilai luhur warisan bangsa yang telah bersentuhan dengan nafas dan semangat keislaman. Semangat ini nampaknya sejalan dengan perkembangan terakhir dimana isu lokalitas menjadi salah satu bentuk upaya menguatkan eksistensi dan ketahanan terhadap gempuran tradisi global yang mengancam jati diri bangsa. Dengan demikian peserta didik bukan sekedar belajar tentang kebudayaannya, namun pada saat yang sama juga mewarisi spirit keislaman dari pendahulunya.

Meski demikian harus diakui bahwa konsep tri ugering ngaurip merupakan konsep yang sangat kental dengan aspek lokalitas. Pengenalan alam pemikiran berbasis naskah klasik dengan nafas Islam dan dihubungkan dengan realitas kekinian semacam ini, tentu hanya dapat dilaksanakan di Pulau Jawa. Meski demikian, konsep tri ugering ngaurip tetap menyediakan nilai-nilai universal yang bisa dipahami oleh masyarakat dari latar belakang budaya yang berbeda. Sebab Jawa juga menjadi bagian dari dunia. Oleh karena itu orang Jawa hendaknya bisa belajar tentang kearifan masa lalu kepada masyarakat dunia dan demikian juga sebaliknya. Di sinilah letak pentingnya mengangkat konsep tri ugering ngaurip ke dalam ranah pendidikan Islam untuk menyediakan alternatif motivasi bagi dunia kewirausahaan.

\section{E. PENUTUP}

Berdasarkan kajian yang telah dilakukan di atas, maka dapat disimpulkan halhal sebagai berikut:

Jurnal Al-Fikri Volume 3 Nomor 1 - Februari 2020 
1. Tri ugering ngaurip merupakan sebagian isi dari Serat Wedhatama, karya K.G.P.A.A. Mangkunegara IV, yaitu sebuah naskah didaktik untuk pengajaran etika dan moralitas. Termasuk di dalamnya membahas tentang etos kerja.

2. Tri ugering ngaurip sendiri merupakan motivasi dalam bekerja dimana sejumlah faktor yang sangat berperan dalam kehidupan dikupas. Diantaranya terdiri dari wirya sebagai bentuk penjagaan kehormatan dan martabat manusia dalam suatu masyarakat, arta yang berdimensi pada terciptanya kemandirian finansial, dan winasis yang mengedepankan kecerdasan multidimensi, terutama kecerdasan intelektual (IQ), emosional (EQ), dan Spiritual (SQ). Ketiga kecerdasan yang terakhir ini sangat berperan dalam menentukan gerak langkah dunia wirausaha.

3. Tri ugering ngaurip pada dasarnya bersentuhan langsung dengan problem eksistensial yang dihadapi manusia. Oleh karena itu maka dapat digolongkan ke dalam masalah asasi (ultimate problems) yang dimiliki oleh manusia.

4. Upaya untuk menyelenggarakan pendidikan Islam yang berwawasan tri ugering ngurip, baik sebagai motivasi dalam menumbuh kembangkan kewirausahaan maupun dalam ranah yang lebih praksis, sejatinya merupakan kewajiban yang sejak awal telah include kepada umat Islam. Terlebih lagi konsep ini berasal dari warisan luhur umat Islam terdahulu di Jawa, bagian dari khazanah kekayaan budaya Nusantara. Dengan demikian, upaya konservasi terhadap konsep tri ugering ngurip bisa dimaknai sebagai usaha untuk membangun perdamaian dengan warisan sejarah masa lalu yang bisa dihayati melalui wujud kebudayaan sarat nilai berupa naskah klasik Jawa. 


\section{DAFTAR PUSTAKA}

Abdullah, Rahmad, 2015, Walisongo: Gelora Dakwah dan Jihad di Tanah Jawa, Surakarta: Penerbit Al-Wafi

Agustian, Ary Ginanjar, 2004, Rahasia Sukses Membangkitkan ESQ Power, Jakarta: Arga

Dakir dan Sardimi, 2011, Pendidikan Islam dan ESQ: Komparasi Integratif Upaya Menuju Stadium Insan Kamil, Semarang: RaSAIL

Kasali, Rhenald, et.all, 2012, Modul Kewirausahaan Untuk Program Strata 1, Cetakan III, Bandung: Mizan Media Utama

Mangunlesana (ed.), Kidung Sesingir: Serat Piwulang Dalem Ingkang Sinuhun Kangjeng Susuhunan Paku Buwana Kaping IX ing Nagari Surakarta Hadiningrat, Surakarta: Pelajar

Poerwadarminta, W. J.S., 1943, Kawi Jarwa, Jakarta: Bale Poestaka.

Santosa, Iwan, 2011, Legiun Mangkunegaran (1808-1942): Tentara Jawa-Perancis Warisan Napoleon Bonaparte, Jakarta: Kompas

Soedjonoredjo, 1937, Wédatama Winardi, Kediri: Tan Khoen Swie

Sugihartono, et all, 2007, Psikologi

Pendidikan, Yogyakarta: UNY Press
Sukri, Sri Suhandjati, 2004, Ijtihad Progresif Yasadipura II dalam Akulturasi Islam dengan Budaya Jawa, Yogyakarta: Gama Media

Sunyoto, Agus, 2016, Atlas Wali Songo: Buku Pertama yang Mengungkap Wali Songo Sebagai Fakta Sejarah, Bandung: Mizan Media Utama

Supadie, Didiek Ahmad, 2015a, Pengantar Studi Islam, Edisi Revisi, Cetakan III, Jakarta: RajaGrafindo Persada

Supadie, Didiek Ahmad, 2015b, Studi Islam II, Jakarta: RajaGrafindo Persada

Tafsir, Ahmad, 2012a, Ilmu Pendidikan Islami, Bandung: Rosdakarya.

Tafsir, Ahmad, 2012b, Filsafat Pendidikan Islami: Integrasi Jasmani, Rohani, dan Kalbu Memanusiakan Manusia, Cetakan V, Jakarta: Rosdakarya

Tjandrasasmita, Uka, 2009, Arkeologi Islam Nusantara, Jakarta: Gramedia

Winter, C. F., 1928, Sêrat Isi Têmbung Kawi Mawi Têgêsipun, Reproductiebedrijf v/d Topografischen Dienst.

Yunus, Mahmud, 2008, Sejarah Pendidikan Islam di Indonesia, Cetakan III, Jakarta: Penerbit Mahmud Yunus Wadzurriyah 